\title{
PENGENALAN AURAT BAGI ANAK USIA DINI DALAM PANDANGAN ISLAM
}

\author{
Alfadl Habibie \\ Universitas Muhammadyah Tasikmalaya \\ Program Studi Pendidikan Teknologi Informasi \\ Email : alfadl@umtas.ac.id
}

\begin{abstract}
ABSTRAK
Anak Usia Dini (Tufulah), adalah masa terbaik dan keemasan (Golden age) untuk menanamkan pondasi yang akan menopang tumbuh kembang, termasuk membangun nilai-nilai dalam kehidupannya termasuk dalam informasi tetang seks. Jika tidak dapat informasi yang tepat maka akan terjadi miskonsepsi yang berakibat fatal. Informasi tentang seks sebaiknya dibagun dengan nilai-nilai keagaman, bahwa seks bagian dari fitrah manusia yang sifatnya wajar dan alamiah terdapat pada semua orang. Selain itu anak mempunyai konsep yang baik tentang seks sebelum masa tamyiz sehingga anak sudah bisa memilah dan memilih prilaku yang sesuai dengan nilai yang dimilikinya, apa yang bermanfat dan merugikan bagi bisa dihindari. Tujuan pendidikan seksual adalah membuat sikap emosional yang sehat terhadap masalah seksual dan membimbing anak kearah hidup dewasa/baligh yang sehat dan bertangungjawab terhadap kehidupan seksualnya. Pada anak usia dini cara memberikan pendidikan seksual adalah mulai memperkenalkan organ organ seks yang dimilki dan konsep aurat melekat padanya secara singkat. Berdasarakan kajian literatur, maka dalam pandangan ajaran Islam pengenalan aurat kepada anak usia dini adalah keharusan sehingga mengetahui aurat manusia baik laki-laki maupun perempuan, mana yang dapat terlihat dan mana yang tidak boleh terlihat, siapa saja yang dapat melihat aurat, pisahkan tempat tidur anak dengan orang tua dan saudara yang berlainan jenis kelamin, kemudian ajak bermain sambil belajar dalam mengenal aurat baik dari buku cerita, nyanyian, maupun film animasi anak.
\end{abstract}

Kata Kunci : Aurat; Anak Usia Dini; Perspektif Islam.

\begin{abstract}
ABSTRACK
Early Childhood (Tufulah), is the best time to instill a foundation that will sustain growth, including building values in his life, including in information about sex. If children can not get the right information then there will be a fatal misconception. Sex information should be built with the values of diversity, that sex is part of human nature that is natural. besides the children have a good concept of sex before tamyiz so that children can sort and choose the behavior in accordance with the value it has, what is beneficial and harmful to be avoided. The purpose of sexual education is to create a healthy emotional attitude towards sexual problems and guide the child towards a healthy adult and responsible for his sexual life. In early childhood how to provide sexual education is to start introducing sex organs and the concept of aurat attached to him briefly. Based on literature study then In the perspective of Islam, the introduction of aurat to early childhood is a necessity so that knowing the human aurat of both men and women, which can be seen and what not to be seen, anyone who can see aurat, separate the child's bed with parents and siblings of different sexes, invite to play while learning in the familiar aurat of the story book, singing, and animated film.
\end{abstract}

Keywords: Aurat; Early childhood; The Perspective of Islam.

\section{PENDAHULUAN}

Masa anak adalah berada pada masa keemasan (the golden age) dalam pertumbuhan dan perkembangan manusia baik secara fisik, emosi, sosial, dan spiritual (Elfan 2017, 3), dan pada masa ini pula awal dimana anak mulai mengenali diri dan sekitarnya. Masa ini sangat penting dalam membangun konsep awal tentang kehidupannya dari segala informasi yang masuk baik informasi baik maupun yang buruk. Dari 
sekain banyak aspek kehidupan salah satunya adalah pengetahuan tentang seks, banyak kasus tetang penyimpnagan seks (sexs abused) yang terjadi di masyarakat seperti halnya kasus pergaluan bebas hingga terjadi free sex berakibat hubungan sebelum nikah, kehamilan diluar nikah, pemerkosaan, LGBT, HIV/AIDS dan lain-lainya. Semua berkaitan dengan moralitas dan bermuara terhadap pemahanan tentang seksualitas dan gender.

Ajaran Islam sebagai sebuah jalan dan sistem kehidupan yang diyakini sangat syumul (lengkap) telah mengatur bagaimana pendidikan seks untuk anak, karena ajaran Islam memiliki konsep bagaimana memberi pemahaman kepada anak-anak tentang seks, walaupun secara teknis dan praktis manusia dituntut untuk mengembangkan dan menggali dari fenomena yang terjadi (ayat-ayat kauniyah). Pembahasan tentang pendidikan seks adalah sebuah tema krusial dan pembahasannya adalah sebuah tanggung jawab besar, karena Islam adalah sebagai agama yang syumul, justru sangat perhatian dengan pendidikan seks (sex education) ini, hal ini diungkapkan oleh seorang ulama besar di Mesir. Beberapa teks syari'at yang menata perilaku seks sangat jelas adanya. Tentu saja pola dan cara pendidikan seks dalam Islam berbeda dengan sex education yang ada di negara-negara barat, karena pendidikan seks dalam Islam senantiasa berpijak dari isyarat dan tata cara yang telah digariskan Allah dan Rasul-Nya dalam al-Qur'an dan hadist.

Diantara contoh pendidikan seks dalam Islam, seperti yang terangkum dalam sex education for children: Panduan Islam bagi orang tua dalam pendidikan seks untuk anak adalah berkenaan dengan anjuran Islam kepada orang tua untuk menjaga adab berhubungan seks, memperhatikan kualitas susuan kepada anak, dan peduli terhadap lingkungan yang kondusif untuk pendidikan seksualitas anak-anak lebih teknis, Islam mendidik para orang tua untuk memisahkan tempat tidur anak perempuan dan anak laki-laki semenjak mereka memasuki usia tamyiz, mengajarkan anak agar meminta izin ketika memasuki rumah orang lain semenjak kecil, tidak mempertontonkan adegan seksual didepan anak-anak yang masih kecil, menseleksi media (bacaan dan tontonan) untuk anak, dan mengontrol teman bermain anak, cara berpakaian, dan yang paling mendasar adalah tentang pengenalan aurat manusia yang boleh terlihat dan tidak boleh terlihat.

Dari fenomena tersebut sudah sewajarnya, jika ada antisipasi dengan memperkenalkan pengetahuan tentang seks sejak Anak Usia Dini (AUD) yang sesuai dengan fitrahnya, sehingga memiliki pemahaman yang benar. Pengetahuan tentang aurat bagi manusia apakah laki-laki maupuan perempuan adalah salah satu upaya dalam memberikan pendidikan seks bagi anak. Oleh karena itu pada tulisan ini akan diuraikan tentang pengenalan aurat dalam pandangan Islam bagi anak usia dini yang tertuang dalam al-Qur'an maupun al-Hadits.

\section{METODE PENELITIAN}

Metode penelitian yang digunakan dalam penulisan artikel ini menggunakan metode kajian pustaka mengenai pengenalan aurat dalam perspektif Islam untuk Anak Usia Dini. Literatur yang dikaji berupa artikel ilmiah, hasil riset, dan buku-buku yang relevan dalam menjawab persoalanpersoalan terkait. 
HASIL DAN PEMBAHASAN

Fase Perkembangan Anak Menurut Konsep Islam

1. Masa bayi (0-2 tahun)

Pada fase ini orang tua perlu untuk mengembangkan kasih sayang secara dua arah dimana ibu memberikan kasih sayangnya dan dalam waktu bersamaan juga mengembangkan kemampuan anak memberikan respon terhadap kita. Ini seperti yang sering kita perhatikan dalam fase pertumbuhan anak secara umum dimana kita memang diharapkan mengajarkan dan memperhatikan anak untuk dapat memberikan respon dengan baik. Meski beberapa orang menganggap hal ini biasa, tapi dalam pengamatan saya pribadi anak tidak akan berkembang maksimal jika orang tua (atau orang sekitar) kurang memberikan stimulasi pada anak. Disini yang dimaksud "mengembangkan kemampuan anak dalam memberikan respon".

2. Masa anak-anak (2-7 tahun atau disebut dengan fase thufulah)

Pada fase inilah merupakan fase penting untuk memberikan fondasi dasar, yaitu mengenalkan tentang sang khalik, mengenalkan asal usulnya, tujuan dan fungsi hidupnya, dan pembelajaran lainnya dengan cara yang atraktif dan sesuai dengan tumbuh kembang anak tersebut. Menurut Maria Montessori anak mesti mencapai tingkat kerohaniahan yang lebih tinggi melalui hal-hal konkrit. Sehingga penananam tauhid pada anak usia dini berbeda perlakuannya seperti kepada orang dewasa, dimana anak tidak dapat berfikir sesuatu yang abstrak tetapi harus konkrit. Ada tidak peranan penting yang saling berkaitan dalam keberhasilan proses pendidikan anak usia dini pada fase ini, yaitu : keluarga, lingkungan, dan sekolah. Dalam pendekatan Reggio Emilia, orang dewasa memiliki peran penting dan kuat dalam kehidupan anak (Morrison, 2016, 315)

3. Masa Tamyiz (7-10 tahun)

Fase ini anak sudah mulai mampu membedakan baik dan buruk berdasarkan nalarnya sendiri sehingga di fase inilah kita sudah mulai mempertegas pendidikan pokok syariat, dengan cara mengembangkan konsep dasar yang telah diajarkan pada fase sebelumnya.

4. Masa Amrad (10-15 tahun)

Fase ini adalah fase dimana anak mulai mengembangkan potensi dirinya guna mencapai kedewasaan dan memiliki kemampuan bertanggung jawab secara penuh. Dalam Islam, fase ini juga merupakan fase dimana anak mencapai aqil baligh sehingga sudah semakin pandai menggunakan akalnya secara penuh. Salah satu yang menjadi tuntutan bagi anak kemudian adalah kepandaiannya dalam mengatur harta yang dimulai dengan kemampuan mengatur anggaran untuk dirinya sendiri sehingga mengerti apa yang sekedar keinginan dan kebutuhannya.

5. Masa Taklif (15-18 tahun) 
Pada masa ini anak seharusnya sudah sampai pada titik bernama taklif atau bertanggung jawab. Bagi lelaki setidaknya fase ini paling lambat dicapai di usia 18 tahun dan bagi anak perempuan paling lambat dicapai di usia 17 tahun. Tanggung jawab yang dimaksud selain pada diri sendiri juga tanggung jawab terhadap keluarga, masyarakat sekitar dan masyarakat secara keseluruhan.

\section{Perkembangan psikoseksual}

Teori perkembangan psikoseksual Sigmund Freud adalah salah satu teori yang paling terkenal, akan tetapi juga salah satu teori yang paling kontroversial. Freud percaya kepribadian yang berkembang melalui serangkaian tahapan masa kanak-kanak dimana mencari kesenangan-energi dari id menjadi fokus pada area sensitif seksual tertentu. Energi psikoseksual atau libido, digambarkan sebagai kekuatan pendorong di belakang perilaku. Menurut Sigmund Freud, kepribadian sebagian besar dibentuk oleh usia lima tahun. Awal perkembangan berpengaruh besar dalam pembentukan kepribadian dan terus mempengaruhi perilaku di kemudian hari.

Jika tahap-tahap psikoseksual selesai dengan tepat, hasilnya adalah kepribadian yang sehat. Jika masalah tertentu tidak diselesaikan pada tahap yang tepat, fiksasi dapat terjadi. fiksasi adalah fokus yang gigih pada tahap awal psikoseksual. Sampai konflik ini diselesaikan, individu akan tetap "terjebak" dalam tahap ini. Misalnya, seseorang yang terpaku pada tahap oral mungkin terlalu bergantung pada orang lain dan dapat mencari rangsangan oral melalui merokok, minum, atau makan. Bukankah ada orang yang berfikiran hanya makan dan makan.

\section{a. Fase Oral}

Pada tahap oral, sumber utama bayi interaksi terjadi melalui mulut, sehingga refleks mengisap adalah sangat penting. Mulut sangat penting untuk makan, bagi bayi yang memicu kesenangan dari rangsangan oral melalui kegiatan memuaskan seperti mencicipi dan mengisap. Karena bayi sepenuhnya tergantung pada pengasuh (yang bertanggung jawab untuk memberi makan anak), bayi juga mengembangkan rasa kepercayaan dan kenyamanan melalui stimulasi oral.

Konflik utama pada tahap ini adalah proses penyapihan, anak harus menjadi kurang bergantung pada para pengasuh. Jika fiksasi terjadi pada tahap ini, Freud percaya individu akan memiliki masalah dengan ketergantungan. fiksasi oral dapat mengakibatkan masalah dengan minum, makan, atau menggigit kuku.

\section{b. Fase Anal}

Pada tahap anal, Freud percaya bahwa fokus utama dari libido adalah pada pengendalian kandung kemih dan buang air 
besar. Konflik utama pada tahap ini adalah pelatihan toilet - anak harus belajar untuk mengendalikan kebutuhan tubuhnya. Mengembangkan kontrol ini menyebabkan rasa prestasi dan kemandirian pada anak.

Menurut Sigmund Freud, keberhasilan pada tahap ini tergantung pada cara di mana orang tua malalui pendekatan pelatihan toilet. Orang tua yang memanfaatkan pujian dan penghargaan untuk menggunakan toilet pada saat yang tepat mendorong hasil yang positif dan membantu anak-anak merasa mampu dan produktif. Freud percaya bahwa pengalaman positif selama tahap ini menjadikan sebagai dasar orang untuk menjadi orang dewasa yang kompeten, produktif dan kreatif.

Namun, tidak semua orang tua memberikan dukungan dan dorongan bahwa anak-anak memerlukan kebutuhan yang tepat selama tahap ini. Beberapa orang tua bukan menghukum, mengejek atau membuat malu seorang anak untuk member efek jera. Menurut Freud, respon orangtua yang tidak sesuai dapat mengakibatkan hasil negatif. Jika orang tua terlalu ketat atau memulai toilet training terlalu dini, Freud percaya bahwa kepribadian kuat-anal berkembang dimana individu tersebut ketat, tertib, kaku dan obsesif.

\section{c. Fase Phalic}

Pada tahap phallic, fokus utama dari libido adalah pada alat kelamin. Anak-anak juga menemukan perbedaan antara pria dan wanita. Freud juga percaya bahwa anak laki-laki mulai melihat ayah mereka sebagai saingan, karena ibu harus berbagi kasih sayang dengannya. Kompleks Oedipus menggambarkan perasaan ini ingin memiliki ibu dan keinginan untuk menggantikan ayah. Namun, anak juga memiliki kekhawatiran bahwa ia akan dihukum oleh ayah untuk perasaan ini.

\section{d. Fase Laten}

Periode laten adalah saat eksplorasi dimana energi seksual tetap ada, tetapi diarahkan ke daerah lain seperti pengejaran intelektual dan interaksi sosial. Tahap ini sangat penting dalam pengembangan keterampilan sosial dan komunikasi dan kepercayaan diri.

Freud menggambarkan fase laten sebagai salah satu yang relatif stabil. Untuk alasan ini, fase ini tidak selalu disebutkan dalam deskripsi teori sebagai salah satu tahap, tetapi sebagai suatu periode terpisah.

\section{e. Fase Genital}

Pada tahap akhir perkembangan psikoseksual, individu mengembangkan minat 
seksual yang kuat pada lawan jenis. Dimana dalam tahap-tahap awal fokus hanya pada kebutuhan individu, kepentingan kesejahteraan orang lain tumbuh selama tahap ini. Jika tahap lainnya telah selesai dengan sukses, individu sekarang harus seimbang, hangat dan peduli. Tujuan dari tahap ini adalah untuk menetapkan keseimbangan antara berbagai bidang kehidupan.

\section{Pendidikan seksual}

Pendidikan seksual adalah suatu informasi mengenai persoalan seksualitas manusia yang jelas dan benar, yang meliputi proses terjadinya pembuahan, kehamilan sampai kelahiran, tingkah laku seksual, hubungan seksual, dan aspek-aspek kesehatan, kejiwaan dan kemasyarakatan (Sarwono, 2006). Masalah pendidikan seksual yang diberikan sepatutnya berkaitan dengan norma-norma yang berlaku di masyarakat, apa yang dilarang, apa yang dilazimkan dan bagaimana melakukannya tanpa melanggar aturan -aturan yang berlaku di masyarakat (Zainun, 2009).

Pendidikan seksual adalah suatu kegiatan pendidikan yang berusaha untuk memberikan pengetahuan agar mereka dapat mengubah perilaku seksualnya ke arah yang lebih bertanggungjawab. Pendidikan seksual seharusnya diberikan oleh orangtua sejak dini ketika anak mulai bertanya tentang perbedaan kelamin. Pendidikan seksual diberikan sesuai dengan kebutuhan dan umur serta daya tangkap anak (Sumiati, 2009).
Pendidikan seks adalah salah satu cara untuk mengurangi atau mencegah penyalahgunaan seks, khususnya untuk mencegah dampakdampak negatif yang tidak di harapkan, seperti kehamilan yang tidak di rencanakan, penyakit menular seksual, depresi dan perasaan berdosa (Sarwono, 2007). Dalam ajaran Islam pendidikan seks diajarkan dengan sangat bijaksana sesuai dengan tumbuh kembang anak, sehingga tidak terkesan vulgar atau menjurus pada arah pornografi maupun porno aksi. Pada anak usia dini diawali dengan mengenalkan perbedaan kelamin laki-laki dan perempuan, pengetahuan siapa yang dapat dan tidak dapat menyentuh halhal yang vital pada diri anak, kemudian pengetahuan yang dikonkritkan dengan memberikan pakaian anak, mana bagian yang dapat terlihat dan mana yang harus tertutupi.

\section{Aurat}

Menurut bahasa "aurat" berarti malu, aib, dan buruk. Kata aurat berasal dari bahasa arab yaitu: 'awira" artinya hilang perasaan, kalau dipakai untuk mata, maka mata itu hilang cahayanya dan lenyap pandangannya. Pada umumnya kata ini memberi arti yang tidak baik dipandang, memalukan dan mengecewakan. Selain daripada itu kata aurat berasal dari kata "“ $\bar{a} r a$ ",artinya menutup dan menimbun seperti menutup mata air dan menimbunnya. Ini berarti, bahwa aurat itu adalah sesuatu yang ditutup sehingga tidak dapat dilihat dan dipandang. Selanjutnya kata aurat berasal dari kata "a'wara" artinya, sesuatu yang jika dilihat, akan mencemarkan. Jadi, aurat adalah suatu anggota badan yang harus 
ditutup dan dijaga hingga tidak menimbulkan kekecewaan dan malu (Yanggo, 2010).

Menurut istilah, dalam pandangan pakar hukum Islam, aurat adalah bagian dari tubuh manusia yang pada prinsipnya tidak boleh kelihatan, kecuali dalam keadaan darurat atau kebutuhan yang mendesak (Shihab, 2010), sedangkan menutup aurat dalam pengertian hukum Islam berarti menutup dari batas minimal anggota tubuh manusia yang wajib ditutupinya karena adanya perintah dari Allah SWT. Adanya perintah menutup aurat ini karena aurat adalah anggota atau bagian dari tubuh manusia yang dapat menimbulkan birahi atau syahwat dan nafsu bila dibiarkan terbuka. Bagian atau anggota tubuh manusia tersebut harus ditutupi dan dijaga karena ia (aurat) merupakan bagian dari kehormatan manusia (Mujadiddul Islam dan Lailatus Sa`adah, 2011).

Dengan demikian, pengertian aurat adalah anggota atau bagian dari tubuh manusia yang apabila terbuka atau tampak akan menimbulkan rasa malu, aib, dan keburukan-keburukan lainnya.Berdasarkan pengertian di atas, juga dapat disimpulkan bahwa menutup aurat atau menutupi anggota tubuh tertentu bukan beralasan karena anggota tubuh tersebut kurang bagus atau jelek, namun lebih mengarah pada alasan lain, yaitu jika tidak ditutupi maka akan dapat menimbulkan malu, aib, dan keburukan. Oleh sebab itu hendaknya manusia menutup bagian tersebut sehingga tidak dapat dilihat oleh orang lain.

Batasan aurat laki-laki dari pusar sampai lutut sedangkan perempuan seluruh anggota tubuh kecuali muka dan telapak tangan. Kepada siapa saja batasan orang bisa melihat atau yang disebut dengan mahram yaitu laki-laki dengan lakilaki lagi, perempuan dan permpuan lagi, dan dewasa dengan anak-anak.

Menutup aurat adalah tanda atas kesucian jiwa dan baiknya kepribadian seseorang. Jika ia diperlihatkan maka itu bukti atas hilangnya rasa malu dan matinya kepribadian. Sudah menjadi tugas setan beserta sekutu -sekutunya dari jin dan manusia, membujuk umat muslimin laki-laki maupun perempuan agar sudi kiranya menanggalkan pakaian-pakaian suci serta selendang pembalut kehormatan mereka (Abdul Aziz, 2004) .

Aurat yang terbuka akan memberi dan juga mendatangkan dampak negatif bagi yang bersangkutan dan terutama bagi yang melihat. Seseorang yang tidak berperasaan malu apabila terbuka auratnya, atau bahkan merasa senang dan bangga apabila auratnya dipandang dan dinikmati oleh orang lain. Terutama pada anak perempuan pengenalan aurat menjadi sangat urgen sehingga dengan pengetahuan dan kemampuan untuk menutup aurat menjadikan anak tersebut aman. Banyak dalil perintah tentang kewajiban untuk menutup aurat diantaranya :

1) Katakanlah kepada wanita yang beriman, "Hendaklah mereka menahan pandangannya, dan memelihara kemaluannya, dan janganlah mereka menampakkan perhiasannya, kecuali yang (biasa) nampak dari padanya. Dan hendaklah mereka menutupkan kain kudung ke dadanya, dan janganlah menampakkan perhiasannya, 
kecuali kepada suami mereka, atau ayah mereka, atau ayah suami mereka, atau puteraputera mereka, atau puteraputera suami mereka, atau saudara-saudara laki-laki mereka, atau putera-putera saudara laki-laki mereka, atau putera-putera saudara perempuan mereka, atau wanitawanita islam, atau budak-budak yang mereka miliki, atau pelayan-pelayan laki-laki yang tidak mempunyai keinginan (terhadap wanita) atau anakanak yang belum mengerti tentang aurat wanita. Dan janganlah mereka memukulkan kakinya agar diketahui perhiasan yang mereka sembunyikan. Dan bertaubatlah kamu sekalian kepada Allâh, wahai orangorang yang beriman supaya kamu beruntung. (Q.S an-Nûr (24):31).

2) Wahai anak adam, pakailah pakaianmu yang indah di setiap (memasuki) masjid, makan dan minumlah, dan jangan berlebihlebihan. Sesungguhnya Allâh tidak menyukai orang-orang yang berlebihan. (Q.S al-A'râf (7):31).

3) Wahai Nabi, katakanlah kepada isteri-isterimu, anak-anak perempuanmu dan isteri-isteri orang Mukmin, "Hendaklah mereka mengulurkan jilbabnya ke seluruh tubuh mereka !" Yang demikian itu supaya mereka lebih mudah untuk dikenal, karena itu mereka tidak di ganggu. dan Allâh adalah Maha Pengampun lagi Maha Penyayang. (Q.S. al-Ahzâb (33):59).

4) Wahai Asma ! Sesungguhnya wanita jika sudah baligh maka tidak boleh nampak dari anggota badannya kecuali ini dan ini (beliau mengisyaratkan ke muka dan telapak tangan). (HR. Abu Dâwud, no. 4104 dan alBaihaqi, no. 3218. Hadist ini di shahihkan oleh syaikh al-Albâni rahimahullah).

5) Janganlah seorang lelaki melihat aurat lelaki (lainnya), dan janganlah pula seorang wanita melihat aurat wanita (lainnya). Seorang pria tidak boleh bersama pria lain dalam satu kain, dan tidak boleh pula seorang wanita bersama wanita lainnya dalam satu kain." (HR. Muslim, no. 338 dan yang lainnya)

Berdasarkan pemaparan tersebut pengenalan aurat anak, mana yang dapat terlihat dan mana yang tidak boleh terlihat adalah awal dari pendidikan seks, dimana anak mengetahui bagian dirinya yang dapat terlihat oleh orang lain, dan mana yang harus tertutup dan tidak dapat dilihat orang lain, terlebih disentuh oleh orang lain, bahkan ketika anak memasuki usia 7 (tujuh) tahun, harus mulai dipisahkan tempat tidurnya baik dengan orang tuanya, maupun saudaranya yang berlainan jenis kelamin.

\begin{tabular}{lcrr}
\multicolumn{2}{c}{ Pengenalan } & aurat & selain \\
dengan cara & \multicolumn{2}{c}{ memebrikan } \\
pengetahuan & mana & yang & harus \\
ditutup dan mana yang boleh
\end{tabular} terbuka, serta adanya upaya memisahkan anak dari saudaranya yang berlainan jenis kelamin, masih banyak cara misalnya mengajak anak untuk membaca buku cerita tentang aurat, mendownload aplikasi edukasi dalam bentuk animasi tentang aurat serta hal-hal yang harus dilakukan untuk menjaga auratnya, bisa juga dengan nyanyian. Pada prinsipnya 
pengenalan aurat pada anak haruslah dilakukan dengan cara yang kreatif dan menarik minat anak, biasanya melalui kegiatan bermain sambil belajar.

\section{SIMPULAN}

Pendidikan seks untuk anak haruslah diajarkan sejak anak usia dini, tetapi sesuai dengan tumbuh kembang anak, dalam pandangan ajaran Islam hal pertama yang dapat dilakukan adalah pengenalan aurat manusia baik laki-laki maupun perempuan, mana yang dapat terlihat dan mana yang tidak boleh terlihat, siapa saja yang dapat melihat aurat, pisahkan tempat tidur anak dengan orang tua dan saudara yang berlainan jenis kelamin, kemudian ajak bermain sambil belajar dalam mengenal aurat baik dari buku cerita, nyanyian, maupun film animasi anak. 
DAFTAR PUSTAKA

Abu Mujadiddul Islam Mafa, dan Lailatus Sa'adah. 2011. Memahami Aurat dan Perempuan. Lumbung Insani.

Elfan Fanhas F Kh, Pendidikan Karakter untuk Anak Usia Dini. Artikel disampaikan pada seminar nasional di UM Surabaya 24 November 2017.

George S Morrison (2016). Pendidikan Anak Usia Dini Saat Ini Edisi 13 (penerj Yudi Santoso). Yogyakarta : Pustaka Pelajar

Huzaemah Tahido Yanggo, 2010. Fikih Perempuan Kontemporer. Jakarta : Ghalia Indonesia

Kementrian Agama RI (2014). AlQur'an dan terjemahnya. Solo : Tiga Serangkai Pustaka Mandiri

M. Quraish Shihab (2004). Jilbab Pakaian Perempuan Muslimah. Jakarta: Lentera Hati.

Sa'ad Yusuf Abdul Aziz (2004). 101 Wasiat Rasul untuk Perempuan, (diterj. oleh Muhammad Hafidz). Jakarta: Pustaka Al-Kautsar.

Sarwono, S.W. (2007). Psikologi Remaja. Jakarta: PT Raja Grafindo Persada

Sumiati, dkk. (2009). Kesehatan Jiwa Remaja \& Konseling. Jakarta: Trans InfoMedia.

belajarpsikologi.com/tahap perkembangan - psikososialmenurut-sigmund-freud/

https://epugi.wordpress.com/2013/11/. ./fase-perkembangan-anakdalam-konsep-isla... http://www.detiknews.com/read/2010/ 11/ 28143410/1504233.Zainun. 2009. Seks Bebas pada Remaja. 